\title{
Flexible Working Hours versus Quality of Life: A Case Study of loBM
}

\author{
Umair Zia* \\ Dr. Amanat Ali Jalbani
}

\begin{abstract}
Flexible work arrangement provides employees with some limited discretion as to the starting and stopping for their work day, while requiring some core hours. Thus according to many prominent researchers, it provides employees some control and independence over their lives. This study would try to present the findings of research carried out mainly among loBM faculty for the purpose of investigating/establishing a relationship between flexible work schedules and quality of life of employees under Pakistani working and living conditions. Researchers believe that every culture has different sets of variables to measure quality of life. Western countries may give importance to family life where as in a different culture economic independence might become a very important variable to measure quality of life. In this research, researchers will try to highlight variables specific to Pakistani environments and their impact on employees. Dependent variables may range from ease in commutation, better sleep quality to better concentration. Researchers have selected 42 faculty members (21 each of male and female) out of 65 employees from IoBM for the main survey as IoBM has already implemented the system. Researchers have tried to use descriptive and correlation analysis to establish trends between quality of life and gender, marital status etc. Researchers believe that this study would at least create awareness among employers about the benefits of flextime, and thus create avenues towards humanistic approach.
\end{abstract}

Keywords: Flexible work arrangements, quality of life

\section{Introduction}

With the advent of humanistic approach in Organizational Development, the West has turned its attention towards development of human capital. The West has started recognizing humans as tools for value addition, for optimizing these tools; they are focusing more now on human side rather than scientific management. However, we need to analyze whether Pakistani organizations have kept pace with this change. Researchers have endeavored to analyze this situation by narrowing it down to one aspect of humanistic approach, namely flextime schedules. In the ensuing paragraphs, researchers have tried initially to define the true concept of flextime, moving to variables involved and finally critique of the literature available vis-à-vis Pakistani environment.

This study is aimed at finding relationship between various flexi hours and perceived quality of life attached with them, by different set of employees in business schools of

*Umair Zia, faculty Institute of Business Management (IoBM), umairzia79@hotmail.com Dr. Amanat Ali Jalbani is a Professor of Management Science at SZABIST, Karachi 
Karachi. The main objective of study is to establish a relationship between various flexi hours schedule and their effects on employees. These effects are bracketed in terms of gender, marital status, and family size. Thus providing guidelines for employers who want to initiate flexi hours in their organizations.

The limitation of the study is that it is focused on employees (faculty) of business schools. At times, this limited scope generates findings which are peculiar to a specific environment. Caution may be exercised in projecting these findings for other types of organizations.

\subsection{Significance}

As indicated above, flextime has emerged as a potent tool for not only maintaining quality of life but also in turn boosting motivation levels of employees. Females have appeared as predominant gainers out of flextime. However significance of the same has remained below par under Pakistani environment.

Most of the private and public organizations are either reluctant to initiate these programs (mostly due to productivity concerns) or they have indulged in these programs just for the sake of cosmetic changes. Researchers envisage that this research would highlight areas for employers to use flextime programs as motivational tools in increasing productivity of the organization.

\subsection{Methodology}

Researchers have focused on both qualitative and quantitative research. For qualitative research secondary data/focused group interviews were used .For quantitative research Institute of Business Management (IoBM) was chosen out of five major Business Schools of Karachi.

Questionnaire was used for loBM. In all 42 faculty members out of the total of 65 were questioned ( 21 males and 21 female). We made efforts to interview all of the faculty members; however some were unavailable and few refused.

\subsection{Hypothesis}

- Perception of quality of life is independent of gender

- Perception of quality of life is independent of family size

- $50 \%$ of employees believe that flexi hour system has improved workplace

\subsection{Variables}

\subsubsection{Independent Variable}

- Gender

- $\quad$ Family size 


\subsubsection{Dependent Variable}

- $\quad$ Time Devoted to family

- Ease in commutation

- Personal Commitment

- $\quad$ Stress

\section{Literature Review}

According to Hyland (2002), unlike other flexible work arrangements, flextime focuses mainly on the work schedule and does not alter the location of work or the total number of hour's workday. According to Christesen (1990), flexible working hours provide employees with some flexibility as to the starting and stopping for their work day, while requiring a core number of hours to be worked within a given time period. The Conference Board of Boston college reports that nearly half of the employees (out of 2000 households surveyed) who were retiring said that more flexible work schedule would make them stay (Fact Sheet Boston college 2008).

'Under a flextime, employees exercise a decision about the time of day they will arrive at and leave from work. The employer/employee creates a band of core time where each employee must be present (normally 9 or 10 a.m. to 2 or 3 p.m.). For example, a flexible schedule where all employees have to be present from 10 a.m. to 3 p.m. would have 5 core hours. Employees are allowed to come before the core start time and leave after the core finish time, but there is a limit as to how early the employees can arrive and how late they can leave (e.g., cannot start before 8 a.m. and cannot stay past 10 p.m.). Another important aspect is the degree of carryover that is allowed. Some organizations do not allow any carryover of hours (i.e., the employee must work 8 hours per day), whereas others allow carryover on a weekly basis, and a few organizations even allow monthly carryover'. (Baltes et. al, 1999: p. 497)

According to Peter Berg (2004), work arrangements that reflect employers/employees requirement for greater flexibility, employees' requirement for job security and better balance between work and life responsibility are changing today's organization. Implementation of work arrangements with flextime such as part time, telecommuting, compressed workweeks, weekly hour agreements, banking (taking forward your extra worked hours) has increased since 1990. The standard 40 hours work week is disappearing. In many professions, employees regularly put in extra hour to meet deadlines, which eventually create conflict with family life. Same was emphasized by Golden (2002). This need may be obvious in females as female worker needs more flexible schedule and greater control over work in order to better manage children.

Christopher (1992) found that conflict between work and family role decreases employee's perception of quality of work life and quality of family life which in turn impact organizational 
outcomes. They suggest that organizations can mitigate work-family conflicts by offering flexible arrangements. This awareness has given rise to various work arrangements, like maternity leaves, vacation leave and flexible working hours. 'Around the world, managers are becoming more knowledgeable of a changing demographic, cultural, and humanistic need of employees and one way they have reacted is through flexible working hours. In a 1991 study of 188 largest companies in 30 industries $77 \%$ reported that they follow flexible working hours.' (Galinsky, 1991: p .16).

Literature (e.g Swart, 1974, Nollen and Martin, 1978) suggests that organizational attendance, and job behavior tend to show a favorable relationship with flextime, performance results tend to be inconsistent either favorable or neutral, however symptom of stress seem to decline with flextime. Martin (1999) suggests that quality of life actually decreased in terms of mental health as their sleep duration uncertainty increased. According to Mathieu, gender may also play an important role in determining how perception about quality of life has changed. Females may benefit more than men in solving their work family conflict. "Both genders in flexible organizations reported significantly more variations, independence and ability to learn more skills at work, systolic blood pressure, heart rate and epinephrine levels were more in assembly line than flexible organizations, female showed considerably normal levels under flexible environments". (Bo Melin, 1999: p.47)

To take the argument further, according to Imada (1997) in Japan discussion of flexi time has since the beginning of 1990s has been more focused in terms of what constitute a comfortable lifestyle. Scharlach and Boyd (1989) reported a reasonable percentage of workers were providing help to elderly family members and that formal organizational supportive programs were considered extremely helpful in managing care giving and work responsibility conflicts. Offering of such programs may affect behavior of employees, including commitment and job satisfaction. These decisions may be related to employee loyalty to the organization because the organization is perceived to be a 'family friendly' to work in. 'Reasons cited by organization decision-makers for implementing flexible work hours are to improve motivation and morale and to enable employees to better balance work and family' (Kush and Stroh, 1994). Ultimately this flexibility may relate to improved productivity as well. Osterman (1995) found strong link between the implementation of work-family policies and direct efforts on the part of employers to improve employee commitment. Golden (2005) concluded from his study that workers at times are more interested in changing hours rather than reducing volume of hours. Campagna (1981) highlighted that attendance increased in employees following flexi hours.

Advantages and disadvantages of flexible work hours have been discussed (Christensen and Staines, 1990; Golembewski and Proehl, 1978; Glueck, 1979: Kopelman, 1986; Kush and Stroh, 1994 \&1982; Pierce and Newstrom, 1980). Major advantages claimed include decrease in stress, increased job satisfaction and empowerment, reduced slackness and absenteeism, and improved job productivity. Major disadvantages identified include increased costs, problems with work coordination, and difficulties with supervising, and modification in the organizational culture. 


\section{Flexible Hour and Quality of Life in Pakistan}

All of the aforementioned results and findings relate to Western work environments, In Pakistani work place, researchers believe that unique dynamics, cultural bondages and various external variables exist. Highlighting these extraneous variables under Pakistani work place situation would be the major task of the researchers. In the initial, focused group interviews variables which were highlighted by Faculty of loBM included usage of flextime in relation to avoidance of law and order situation, rain, engaging in family commitments, late night commitments and giving more time to children.

\section{Flexible Hour and Quality of Life at loBM - Data Analysis}

\subsection{Gender Based Analysis}

Researcher analyzed the data based on perception about quality of life and gender. As highlighted in table 4.1.1(below), test for independence was used to accept or otherwise the first hypothesis that perception about quality of life vis-à-vis flextime is independent of gender. Analysis showed that 18 out of 21 males had a positive perception towards utility of flextime as against 10 out of 21 in females, rest 11 respondents had either neutral opinion or few had partial opinion .When test for independence was applied on the data for Null hypothesis, Pearson chi square value of 6.857 was established with .009 significance. Thus Null hypothesis was not accepted and it was assumed that perception about flextime is dependent on gender with more males favoring flextime.

Table- 4.1.1

Gender * Perception about Quality of life Crosstabulation Count

\begin{tabular}{|ll|c|c|c|}
\hline \multicolumn{5}{|c|}{ Perception about Quality of life } \\
\hline \multirow{2}{*}{ Gender } & Male & Positive & Neutral & Total \\
& Female & 18 & 3 & 21 \\
\cline { 3 - 5 } & & 28 & 11 & 21 \\
\hline Total & & 14 & 42 \\
\hline
\end{tabular}

Table - 4.1.2: Test for Independence

Chi-Square Tests

\begin{tabular}{|c|c|c|c|c|c|}
\hline & Value & df & $\begin{array}{l}\text { Asymp. Sig. } \\
\text { (2-sided) }\end{array}$ & $\begin{array}{l}\text { Exact Sig. } \\
\text { (2-sided) }\end{array}$ & $\begin{array}{l}\text { Exact Sig. } \\
\text { (1-sided) }\end{array}$ \\
\hline Pearson Chi-Square & $6.857^{\mathrm{b}}$ & 1 & .009 & \multirow{6}{*}{.020} & \multirow{6}{*}{.010} \\
\hline Continuity Correction ${ }^{2}$ & 5.250 & 1 & .022 & & \\
\hline Likelihood Ratio & 7.178 & 1 & .007 & & \\
\hline Fisher's Exact Test & & & & & \\
\hline $\begin{array}{l}\text { Linear-by-Linear } \\
\text { Association }\end{array}$ & 6.694 & 1 & .010 & & \\
\hline $\mathrm{N}$ of Valid Cases & 42 & & & & \\
\hline
\end{tabular}

a. Computed only for a $2 \times 2$ table

b. 0 cells $(.0 \%)$ have expected count less than 5 . The minimum expected count is 7.00 . 
Table - 4.1.3: Graphical Presentation

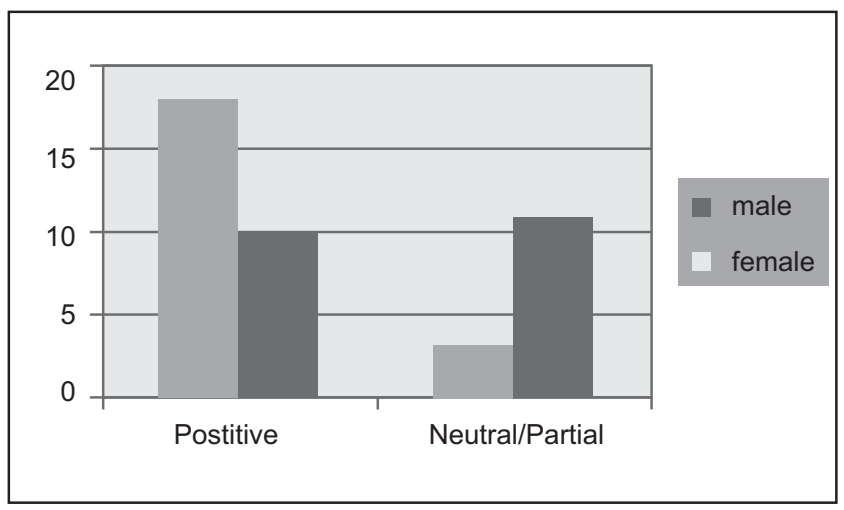

Similarly, when same test was conducted for gender based perception about flextime and its utility in avoidance of traffic jams test for independence again supported at .000 significant level that males have a stronger inclination towards flextime, having more utility in avoidance of traffic jams. Females were found to be more neutral. In all, 20 males answered the question in positive and only 1 answered in neutral, where as this ratio was 12 and 9 in the case of females.

Table - 4.1.4: Gender vs. Traffic Problem

\section{Gender * Traffic Problem Crosstabulation}

Count

\begin{tabular}{|ll|r|r|r|}
\hline & & \multicolumn{2}{|c|}{ Traffic Problem } & \multirow{2}{*}{ Total } \\
\cline { 3 - 4 } & & Neutral/Partial & Positive & \multicolumn{1}{|c|}{ Tot } \\
\hline Gender & male & 1 & 20 & 21 \\
& female & 12 & 9 & 21 \\
Total & & 13 & 29 & 42 \\
\hline
\end{tabular}

Table - 4.1.5: Test of Independence

Chi-Square Tests

\begin{tabular}{|l|c|r|r|r|r|}
\hline & \multicolumn{1}{|c|}{ Value } & df & $\begin{array}{c}\text { Asymp. Sig. } \\
\text { (2-sided) }\end{array}$ & $\begin{array}{r}\text { Exact Sig. } \\
\text { (2-sided) }\end{array}$ & $\begin{array}{r}\text { Exact Sig. } \\
\text { (1-sided) }\end{array}$ \\
\hline Pearson Chi-Square & $13.480^{\circ}$ & 1 & .000 & & \\
Continuity Correction & 11.141 & 1 & .001 & & \\
Likelihood Ratio & 15.250 & 1 & .000 & & .000 \\
Fisher's Exact Test & & & & .000 \\
Linear-by-Linear & 13.159 & 1 & .000 & & \\
Association & 42 & & & & \\
N of Valid Cases & 42 & & & \\
\hline
\end{tabular}

a. Computed only for a $2 \times 2$ table

b. 0 cells $(.0 \%)$ have expected count less than 5 . The minimum expected count is 6.50 . 
Table - 4.1.6: Graphical Representation

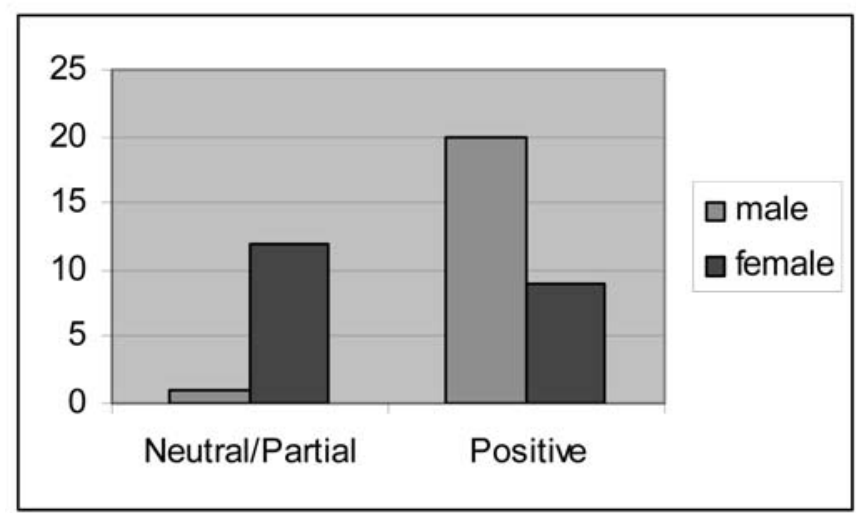

When the respondents were asked that do they believe that implementation of flextime has helped them in resolving their family commitments. Response was once again highly in favor of flextime as 28 out of 39 responded in positive. However as previously response of females was more towards neutral as compared to males, same was supported at significance level of .004

Table - 4.1.7: Gender vs. Family Commitment

\section{Gender * Family Commitments Crosstabulation}

\begin{tabular}{|c|c|c|c|c|}
\hline \multicolumn{5}{|l|}{ Count } \\
\hline & & \multicolumn{2}{|c|}{ Family Commitments } & \multirow[b]{2}{*}{ Total } \\
\hline & & Neutral/Partial & Positive & \\
\hline \multirow[t]{2}{*}{ Gender } & male & 1 & 17 & 18 \\
\hline & female & 10 & 11 & 21 \\
\hline Total & & 11 & 28 & 39 \\
\hline
\end{tabular}

Table - 4.1.8: Test of Independence

Chi-Square Tests

\begin{tabular}{|c|c|c|c|c|c|}
\hline & Value & df & $\begin{array}{c}\text { Asymp. Sig. } \\
\text { (2-sided) }\end{array}$ & $\begin{array}{l}\text { Exact Sig. } \\
\text { (2-sided) }\end{array}$ & $\begin{array}{l}\text { Exact Sig. } \\
\text { (1-sided) }\end{array}$ \\
\hline Pearson Chi-Square & $8.469^{5}$ & 1 & .004 & \multirow{6}{*}{.005} & \multirow{6}{*}{.004} \\
\hline Continuity Correction & 6.519 & 1 & .011 & & \\
\hline Likelihood Ratio & 9.612 & 1 & .002 & & \\
\hline Fisher's Exact Test & & & & & \\
\hline $\begin{array}{l}\text { Linear-by-Linear } \\
\text { Association }\end{array}$ & 8.252 & 1 & .004 & & \\
\hline $\mathrm{N}$ of Valid Cases & 39 & & & & \\
\hline
\end{tabular}

a. Computed only for a $2 \times 2$ table

b. 0 cells $(.0 \%)$ have expected count less than 5 . The minimum expected count is 5.08 . 
Table - 4.1.9: Graphical Representation

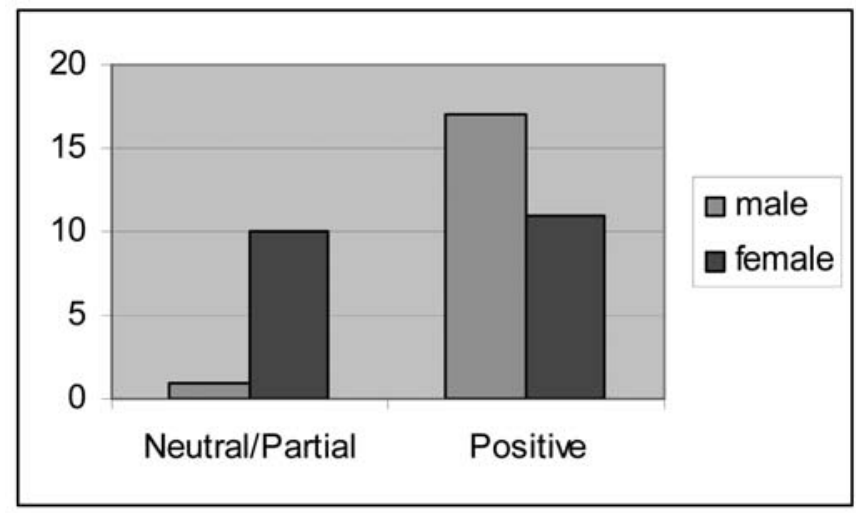

\subsection{Comparison on the Basis of Family Size}

When questions were asked about the overall perception about utility of Flexible timing and results were compared and cross tabulated with family size. Null hypothesis that perception about utility of flextime is independent of family size, could not be rejected with the significance level of 0.243 . However, 16 out of 20 had a positive attitude towards flexi timing as against 12 out of 19 in small families. Overall, 28 out of 39 families supported flexi timing.

Table - 4.2.1:

Family Size Groups * Family Commitments Crosstabulation

Count

\begin{tabular}{|ll|r|r|r|}
\hline \multirow{2}{*}{} & \multicolumn{2}{|c|}{ Family Commitments } & \multirow{2}{*}{ Total } \\
\cline { 3 - 4 } & Neutral/Partial & Positive & \multicolumn{1}{c|}{ Tot } \\
\hline Family Size & Large & 4 & 16 & 20 \\
Groups & Small & 7 & 12 & 19 \\
Total & 11 & 28 & 39 \\
\hline
\end{tabular}

Table - 4.2.2: Test of Independence

Chi-Square Tests

\begin{tabular}{|l|c|r|r|r|r|}
\hline & \multicolumn{1}{|c|}{ Value } & df & $\begin{array}{c}\text { Asymp. Sig. } \\
\text { (2-sided) }\end{array}$ & $\begin{array}{r}\text { Exact Sig. } \\
\text { (2-sided) }\end{array}$ & $\begin{array}{r}\text { Exact Sig. } \\
\text { (1-sided) }\end{array}$ \\
\hline Pearson Chi-Square & $1.365^{\mathrm{b}}$ & 1 & .243 & & \\
Continuity Correction & .660 & 1 & .417 & & \\
Likelihood Ratio & 1.376 & 1 & .241 & & .301 \\
Fisher's Exact Test & & & & .209 \\
$\mathrm{~N}$ of Valid Cases & 39 & & & & \\
\hline
\end{tabular}

a. Computed only for a $2 \times 2$ table

b. 0 cells $(.0 \%)$ have expected count less than 5 . The minimum expected count is 5.36 . 
Table - 4.2.3: Graphical Representation

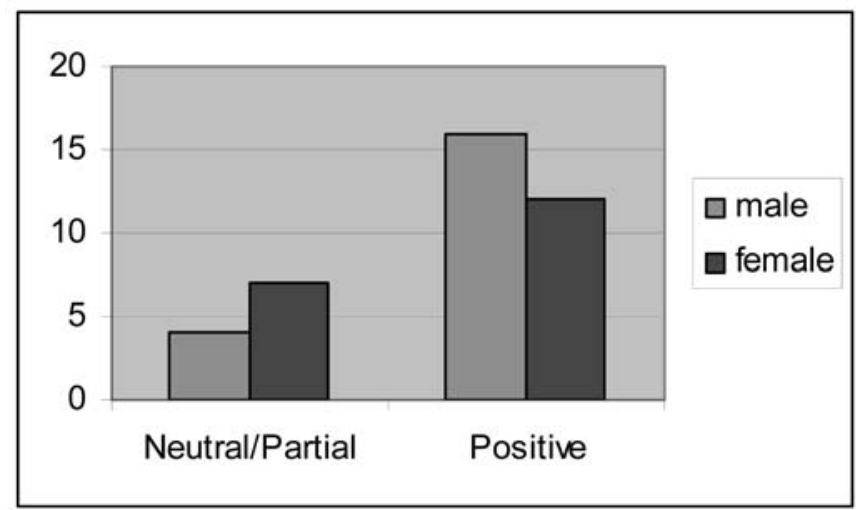

\subsection{Perception about Quality of life vs. Marital Status}

When the perception about quality of life was analyzed with respect to marital status, the researcher found that married people have more positive perception about improvement of quality of life due to flexi timing implementation. 20 out of 25 had a positive perception as against 8 out of 17 of unmarried people. This perception was also proved by test for independence at significance level of 0.026 .

Table - 4.3.1:

\section{Martial Status * Perception about Quality of life Crosstabulation}

Count

\begin{tabular}{|ll|r|r|r|}
\hline \multirow{2}{*}{} & \multicolumn{2}{|c|}{$\begin{array}{c}\text { Perception about Quality of } \\
\text { life }\end{array}$} & \multirow{2}{*}{ Total } \\
\cline { 3 - 4 } & Positive & Neutral/Partial & Totar \\
\hline Martial & Married & 20 & 5 & 25 \\
Status & Not Married & 8 & 9 & 17 \\
Total & 28 & 14 & 42 \\
\hline
\end{tabular}

Table - 4.3.2: Test of Independence

Chi-Square Tests

\begin{tabular}{|c|c|c|c|c|c|}
\hline & Value & df & $\begin{array}{c}\text { Asymp. Sig. } \\
\text { (2-sided) }\end{array}$ & $\begin{array}{l}\text { Exact Sig. } \\
\text { (2-sided) }\end{array}$ & $\begin{array}{l}\text { Exact Sig. } \\
\text { (1-sided) }\end{array}$ \\
\hline Pearson Chi-Square & $4.941^{b}$ & 1 & .026 & \multirow{6}{*}{.045} & \multirow{6}{*}{.030} \\
\hline Continuity Correctiona & 3.570 & 1 & .059 & & \\
\hline Likelihood Ratio & 4.939 & 1 & .026 & & \\
\hline Fisher's Exact Test & & & & & \\
\hline $\begin{array}{l}\text { Linear-by-Linear } \\
\text { Association }\end{array}$ & 4.824 & 1 & .028 & & \\
\hline $\mathrm{N}$ of Valid Cases & 42 & & & & \\
\hline
\end{tabular}

a. Computed only for a $2 \times 2$ table

b. 0 cells $(.0 \%)$ have expected count less than 5 . The minimum expected count is 5.67 . 
Table - 4.3.3: Graphical Representation

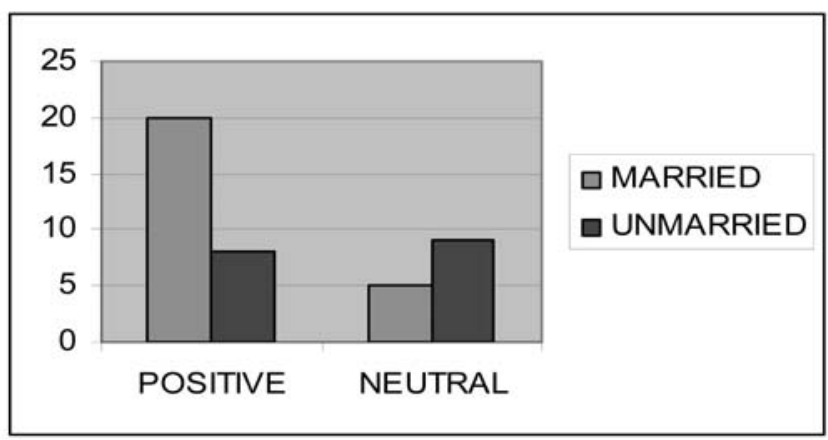

\subsection{Sleeping Hours vs. Flexi Hours}

When respondents were asked whether flextime has improved their sleeping habits, $78 \%$ respondents agreed that flexi timings have improved their sleeping habits. On one sample $T$ test average response on a scale of -3 to +3 came out to be .903 at .004 significant levels.

Table - 4.4.1: Sleeping hours vs Flexi Hours

\section{One-Sample Statistics}

\begin{tabular}{|l|r|r|r|r|}
\hline & $\mathrm{N}$ & \multicolumn{1}{|c|}{ Mean } & Std. Deviation & $\begin{array}{c}\text { Std. Error } \\
\text { Mean }\end{array}$ \\
\hline $\begin{array}{l}\text { Improvement in } \\
\text { Sleeping Habits }\end{array}$ & 42 & .90 & 1.923 & .297 \\
\hline
\end{tabular}

Table - 4.4.2: One Sample Test

One-Sample Test

\begin{tabular}{|c|c|c|c|c|c|c|}
\hline & \multicolumn{6}{|c|}{ Test Value $=0$} \\
\hline & \multirow[b]{2}{*}{$t$} & \multirow[b]{2}{*}{ df } & \multirow[b]{2}{*}{ Sig. (2-tailed) } & \multirow{2}{*}{$\begin{array}{c}\text { Mean } \\
\text { Difference }\end{array}$} & \multicolumn{2}{|c|}{$\begin{array}{l}95 \% \text { Confidence } \\
\text { Interval of the } \\
\text { Difference }\end{array}$} \\
\hline & & & & & Lower & Upper \\
\hline $\begin{array}{l}\text { Improvement in } \\
\text { Sleeping Habits }\end{array}$ & 3.049 & 41 & .004 & .905 & .31 & 1.50 \\
\hline
\end{tabular}

\subsection{Overall Perception about Improvement in Work Pace Due to Flextime}

Null hypothesis that $50 \%$ of employees believed that work place has improved after implementation of flextime, was rejected at $95 \%$ confidence level. And alternate hypothesis that more than $50 \%$ favored the notion was accepted.

Calculated $z=-4.375$ 
Table - 4.5.1: Standard Error

Std. Error of Mean

Missing

$6.41 \mathrm{E}-02$

Table - 4.5.2: Frequency in Work

Overall belief that workplace has improved

\begin{tabular}{|c|c|c|c|c|c|}
\hline & & Frequency & Percent & Valid Percent & $\begin{array}{c}\text { Cumulative } \\
\text { Percent }\end{array}$ \\
\hline \multirow[t]{3}{*}{ Valid } & Improved & 33 & 78.6 & 78.6 & 78.6 \\
\hline & Not Improved & 9 & 21.4 & 21.4 & 100.0 \\
\hline & Total & 42 & 100.0 & 100.0 & \\
\hline
\end{tabular}

Table - 4.5.3: Graphical Representation

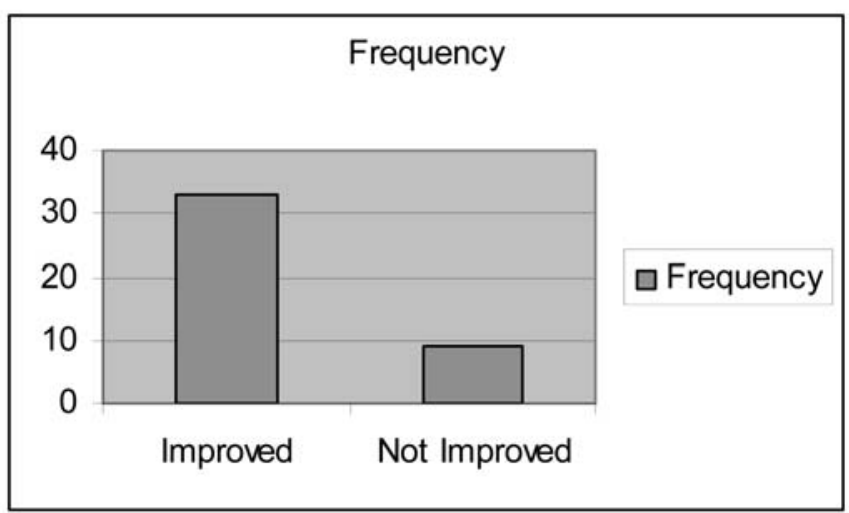

\section{Key Findings}

1). It was found that flexi timings have induced improvement in work place.

2). Factors which have contributed in improvement of work place through flexi timing are: better sleep quality, improved adherence to family commitments, avoidance of traffic jams, and avoidance of other troubled/law and order situations.

3). As against previous researches, perception of females was more towards neutral side than males, who were predominantly inclined towards flexi hours. This may be attributed with the life cycle stage of female and male employees. As most of the females under Pakistani environments join a job specifically in business institutes where probably they have taken care of their other commitments, have achieved financial stability or perusing only one job. On the other hand, males at this stage, at times are not only pursuing two jobs but are also liable to cater to other family needs.

4). There was no relationship established between family size and preference of flextime. 
5). In the context of marital status, the research concludes that married people are more likely to enjoy the facility of flexi timings.

\section{Conclusion}

As the study was mainly focused on faculty of Business Institutes, researchers tried to establish relationship between gender, marital status, size of the family and perception about quality of life. As evident from key findings that there was a relationship between genders, marital status and perception about quality of life due to flexi work schedules. However, no such relationship could be established between family size and perception about quality of life after implementation of flexible working hours.

Researchers would like to highlight that these relationships might be the result of lifecycle stage of employees and their financial status. For example, as we have seen no relationship was established between family size and perception about quality of life. The reason for the same could be larger family size might be indicator of employee who has achieved greater work experience and is financially sound and has resources to handle personal issues without requiring flexi timings.

\section{Recommendations}

In the light of aforementioned, following may be recommended:

- $\quad$ Finding of the report may not be considered in isolation. Due consideration may be given to organizational dynamics, unique culture and lifecycle stage of employees.

- $\quad$ To remain competitive, organizations have to start considering flextime as potent tool for motivation.

- $\quad$ Flextime may be initiated in consultation with employees keeping the culture flexible for adoption. 


\section{References}

1 Baltes, B. B., Briggs, T. E., Huff, J. H., Wright, J. A., \& Neuman, G. A. (1999). 'Flexible and compressed workweek schedules: A meta-analysis of their effects of work-related criteria'. Journal of Applied Psychology Vol. 84, No. 4, pp. 496-513.

2 Bo Melin, ULF Lundberg, Jens Soderlund (1999) 'Psychological and physiological stress reactions of males and females assembly worker', Journal of Organizational Behavior, Vol. 20, pp. 47-61

3 Boston College Research Center (March 2008) 'Fact Sheet: Flexibility at Work', Boston College, p .18.

4 Campagna A. F. and Kim J. S (1981) 'Effect of Flexitime on employees Attendance', Acadamy of Management Journal Vol. 24.

5 Christensen, K. E., \& Staines, G. L. (1990). 'Flextime: A viable solution to work/family conflict?' Journal of Family Issue, Vol. 11, No. 4, pp. 455-476.

6 Christopher, A. Higgins, Linda, E. Duxbury (1992) Journal of Organizational Behavior, Vol. 13. No 4, pp. 389-411.

7 Galanski, E. Friedman, Hernandez, C. (1991) Corporate Reference Guide to Working/family Programmes, New York: Work Institute.

8 Golembewski R.T and Proehl C.W jr (1978) 'A survey on empirical literature on flexi hours' Academy Of Management Review, Vol. 3, pp. 837-853.

9 Golden Appel Baum (2002) 'The standard work day or the highway employers stall in delivering of more flexible arrangements'

10 Golden ,Lonie (2005) 'Solan family research net work', March 2005 Vol. 7, No. 3.

11 Glueck, W. F. (1979) 'Changing hours of work: A review and analysis of the research', The Personnel Administrator, March, pp. 44-47 \& 62-65.

12 Hyland, M. (2002). Chestnut Hill, MA: Sloan Work and Family Research Network.

13 Imada Sachicko (1997) Work and Family Life, Japanese Institute of Labor.

14 Kush, K. S. and Stroh, L. K. (1994). 'Flextime: Myth or reality?' Business Horizons, Vol. 37, pp. 51-55.

15 Kopelman, R. E. (1986). 'Alternative work schedules and productivity: A review of the evidence', National Productivity Review, Spring, pp. 150-165. 
16 Kush, K. S. and Stroh, L. K. (1994) 'Flextime: myth or reality?' Business Horizons, pp. $37 \& 51-55$.

17 Mathieu, J. E. and Zajac, D. M. (1990) 'A review and meta-analysis of the antecedents, correlates and consequences of organizational commitment', Psychological Bulletin, pp. 108 \& 171-194.

18 Martin, M. F. J. (1999) 'Flexible work hours schedule physical and mental health,' Journal of Organizational Behavior, pp. 35- 36.

19 Nollen, S.D. and Martin, V.H. (1978) 'Alternate work schedule part 1 flexi time,' America Management survey Report Amacon

20 Osterman, P. (1995) 'Work/family programs and the employment relationship', Administrative Science Quarterly, Vol. 40, No. 4, pp. 681-700.

21 Pierce J. L and J. W. Newstrom (1980) Towards a Conceptual Clarification of Employees Responses to Flexi Working Hours, Cornel University 23.Transportation Research Board.

22 Peter Berg Eleen, ApplelbaumTombaily (2004) Industrial and Labor Relation Review, p. 57.

23 Scharlach, A. E. and Boyd, S. L. (1989) 'Caregiving and employment: Results of an employee survey', The Gerontologist, Vol. 29, pp. 382-387.

24 Swart, J.C. (1974) 'What time shall I go to work today,' Business Horizons, Vol. 17 , No. 5, pp. 19-26. 